\title{
Yasuo Tsujimura (1913-1979): Constructing the Infrastructure of Special Education and Proposing its Improvement
}

\author{
Makio NAKAMURA* \\ Fukuyama City University, Japan \\ Key Words: Yasuo Tsujimura, special education, special school, special class, separation, community
}

\section{Preface}

Yasuo Tsujimura was a person who enacted various initiatives for the advocacy of people with disabilities. In describing his activities in this report, I will adopt an international perspective. In evaluating Tsujimura's social activity from an international perspective, I would like to mention three main points.

First, he laid the foundations of the Japanese special education system. Interestingly, apart from Western nations, Japan is the only country in which a special education system is so well established.

Second, he contributed to the education of children with mild as well as with profound and multiple disabilities. Appropriate education opportunities had not previously been offered to mildly disabled children or those with profound and multiple disabilities; these children were not subject to compulsory education.

Third, he called attention to the problem of special education students' segregation from the mainstream education, a problem peculiar to the special education system, and proposed solutions to make the education system more inclusive with regard to these students.

This article describes the motives that drove Tsujimura in detail as well as his background, mainly focusing on the three aspects described above.

\footnotetext{
* Corresponding Author

Mailing Address: 2-19-1 Minatomachi, Fukuyama-shi, Hiroshima 721-0964, Japan

E-mail Address: makinaka@nifty.com

Received December 4, 2015, Accepted February 6, 2016

DOI: $10.6033 /$ specialeducation.5.19
}

\section{Promotion of Japan's Special Education System as a Government Official: 1952-1962}

High quality special education systems were only developed in Western countries at the time Tsujimura was a government official. In the non-Western bloc, such system emerged in Japan in 1979. Tsujimura laid the foundation for such a system as the first special education administrative officer. He created the following guidelines and laws which became the core of the system.

The "Guide lines for determining students that require special education" (1953) laid out medical, psychological, and educational criteria for the selection of students for special education.

The "Law to encourage attendance in special schools" (1954) was intended to reduce the excessive economic burden related to attending special schools for the blind, deaf, and other disabled children, and to promote education.

The "Special law to encourage establishment of public special schools for children with mental retardation, physical disability, and diseases" (1956) granted a national subsidy equivalent to that of other compulsory education schools for education of children in these non-compulsory schools. The grant was provided through the Ministry of Education.

The last contribution that Tsujimura made to special education was his editorship of the 80th anniversary publication of the first school for the deaf and the blind. The purpose of this historic book, published in 1958, was to document and assess past policies and education practices, and to propose improvements. 


\section{Proposal of the Educational Development of Children with Mild and Severe Disabilities as a Special Education Researcher}

In 1962, Tsujimura became a Professor at the Ochanomizu Women's University. His goal was to deal with problems emanating from the previous special education policy, on behalf of the Ministry of Education. As chairman of a special research committee, Tsujimura submitted three reports to the Ministry of Education. All three reports proposed fundamental reform of Japanese special education. The first report published in 1969 suggested reorganization of the special education system which was separate and isolated from regular education. Tsujimura's report in 1975 suggested what education should be offered for children with profound and multiple disabilities. This report was intended to provide high quality education for children who were excluded from school education. The last report published in 1978, proposed how to improve education for schoolchildren with mild disabilities in primary and junior high school. These three reports provided proposals to compensate for deficiencies in the special education system that he had previously established.

\section{Reform Proposal Against Segregation in Special Education}

Tsujimura, as the prime promoter, created the special education system. Meanwhile, this system inevitably resulted in segregation of students with disabilities. He noted this as a unique problem in special education that limited disabled students' interaction with other students. He questioned this reality of special education and proposed an education system involving a more integrated relationship with regular education and the non-special community. This proposal is certainly different from the original special education system he promoted. Therefore, this proposal appears to rebel against his earlier proposals. However, this is not the case.

The reason for this is twofold. First, Tsujimura originally placed an emphasis on special education to lay its foundation in the community. He had assumed that the education of children with intellectual disabilities would be implemented in a special class in public schools. This idea was also endorsed by experts in intellectual disabilities education at the time. His policy reflected on the reality at the time. One is that education of the intellectually disabled children had not yet become compulsory, and the other one is that the prefectural special school had not yet been established. Therefore, it was necessary to take advantage of the special classes in public schools rather than special schools. This alternative special education in the form of special class system was very successful. This success was the result of the cooperation of the local education committee as well as the efforts of talented, enthusiastic special class teachers of public schools.

Second, he observed that the separate special school system and a centralized administration produced the success of special education in Japan. However, it does not appear that he supported centralization of power and the uniform school attendance policy, which became evident in special education policy around 1961. In his opinion, special education policy led by the central government was the policy necessary for the establishment of special education system, but not for continued maintenance of the system. In other words, I believe Tsujimura largely objected to the excessive dissociation and isolation of special education from regular education.

\section{Yasuo Tsujimura's Social and Educational Background and Personal Propensity Supported His Special Education System Theory}

The formation of Tsujimura's special education policy was, I believe, possible only among the chaos following the defeat of the last Great War. Among the main education policies, it was difficult to plan and implement an education policy that departed from the General Headquarters, the Supreme Commander for the Allied Powers (GHQ/SCAP)'s governance policies. Special education was only an offshoot of education in general. Prewar special education system of Japan had been inadequately established. However, in the 1980s, it caught up to the level of the advanced Western countries. This rapid development of Japanese special education was the result of the Tsujimura's role, which involved the synthesis of a national government official and university faculty, and the involvement of schoolteachers as special educators, cooperation with parents, public sympathy, the efforts of the Central Education Council, and the 
tax revenue raised by the soon-to-begin high economic growth.

\section{Closing}

If the Japan had lacked any of these mentioned elements, the plans to establish an advanced special education would have collapsed. In fact, these elements greatly weakened since Tsujimura passed away approximately 40 years ago. Although international trends began to move towards inclusive education rather than a separated special education, the Ministry of Education held on to the old type of special education Tsujimura tried to reform. When the Ministry of Education, Culture, Sports, Science, and Technology finally adopted the inclusive education policy recently, the conditions that had allowed promotion of the special education in Tsujimura's era have been lost. Local boards of education have become subcontractors of the central government, university faculty and teachers of special education have both lowered morale, and societal sympathy toward special education has subsided compared to Tsujimura's days.

Tsujimura's reform plan was a result of his own reflection on a separate special education system.
Today, the process he followed in building today's special education policy seems to offer useful insights for reorganizing Japanese style special education, which was made in relation to western style special education.

\section{Endnote}

1) Tsujimura successively held various jobs. His first work was a technical officer in the National Home for the Disabled Soldiers after graduation of Department of Psychology of Tokyo Imperial University. And then, he served as the first Director of the Special Education Office of the Ministry of Education. He was also a professor at the Ochanomizu Women's University, and in his last post, he served as the first Director of the National Institute of Special Education.

\section{References}

Tsujimura, Y. (1972) Special education in transition stage. Nihon Bunka Kagakusha, Tokyo. (in Japanese)

Tsujimura, Y. (1978) New trend in special education. Nihon Bunka Kagakusha, Tokyo. (in Japanese) 